\title{
Exploring human in vivo microcirculation with methyl nicotinate in different perfusion conditions
}

\section{Explorando a microcirculação humana in vivo em diferentes condições de perfusão}

\author{
Henrique Silva ${ }^{1,2 *}$, Catarina Rosado ${ }^{1}$, Joana Antunes ${ }^{2}$ and L. Monteiro Rodrigues ${ }^{1,2}$ \\ ${ }^{1}$ CBIOS - Universidade Lusófona's Research Center for Biosciences and Health Technologies, Campo Grande 376, \\ 1749-024, Lisboa, Portugal \\ ${ }^{2}$ Pharmacol. Sc Depart - Universidade de Lisboa, School of Pharmacy, Lisboa, Portugal \\ Email: henrique.silva@ulusofona.pt
}

*This project is supported by the grant PADDIC 2013-2014, from ALIES-COFAC and part of the PhD Program in Health Sciences from U Alcalá and U Lusófona.

*Este projeto é apoiado pela bolsa PADDIC 2012-2013, da ALIES-COFAC e faz parte do Programa de Doutoramento em Ciências da Saúde da U Alcalá e U Lusófona

\begin{abstract}
Noninvasive technologies, such as Laser Doppler Flowmetry (LDF) and transcutaneous (tc) gasimetry, are useful to assess microcirculation physiology in vivo. Provocation tests, often involving drugs, change perfusion conditions, evoking dynamical responses and respective quantification. Methyl nicotinate (MN) is potent vasodilator, commonly used to test skin reactivity. The purpose of this study was to investigate the cutaneous microvascular reactivity to $\mathrm{MN}$ on the lower limb under different perfusion conditions. The $\mathrm{MN}$-induced vasodilation was recorded in the foot of 15 healthy $(23.1 \pm 3.0)$ years old subjects in two protocols - (1) MN application in a seated position while breathing room atmosphere and while breathing a saturated oxygen atmosphere; (2) MN application while in a supine position and during leg elevation. Several curve-dependent parameters were compared for each protocol by the Wilcoxon matched pairs signed ranks test. A $95 \%$ confidence level was adopted. Results showed no difference in the magnitude of vasodilation when breathing an oxygen atmosphere or a room atmosphere. However, the magnitude of vasodilation decreased significantly when the subject performed a leg elevation from a supine position. Results suggests the usefulness of this model, including MN, to test cutaneous microcirculatory reactivity in vivo
\end{abstract}

Keywords: Microcirculation, LDF, Methyl nicotinate, hyperoxia, postural change

\section{Resumo}

Tecnologias não invasivas, como a Fluxometria por Laser Doppler (FLD) e a gasimetria transcutânea (tc), são úteis para avaliar a fisiologia da microcirculação in vivo. São usados testes de provocação, muitas vezes envolvendo fármacos, que alteram as condições de perfusão, possibilitando respostas dinâmicas e quantificáveis. O nicotinato de metilo (NM) é um potente vasodilatador, usado para testar a reatividade cutânea. O objetivo deste estudo foi investigar a reatividade microvascular ao NM no membro inferior sob diferentes condições de perfusão. A

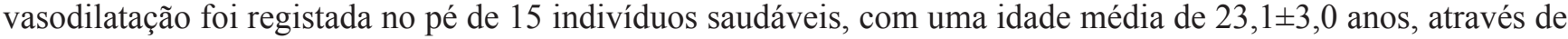
(1) aplicação de NM na posição sentada, respirando ar e uma atmosfera saturada de oxigénio; (2) aplicação de NM, em supinação e durante a elevação da perna. O teste de Wilcoxon para amostras emparelhadas foi escolhido para a estatística comparativa, adoptando-se um nível de confiança de $95 \%$. Os resultados mostraram não existir diferença na magnitude da vasodilatação ao respirar oxigénio ou ar ambiente. No entanto, a amplitude da vasodilatação diminuiu significativamente quando o sujeito foi submetido a uma elevação da perna em supinação. Os resultados sugerem a utilidade deste modelo, incluindo NM para o estudo da reactividade microcirculatória da pele in vivo.

Palavras-chave: Microcirculação, FLD, Nicotinato de metilo, hiperóxia, alteração postural 


\section{Introduction}

Skin provides an easily-accessible vascular bed for the study of physiological and dysfunctional blood flow regulation mechanisms ${ }^{[1,2]}$. Laser Doppler Flowmetry (LDF) and Transcutaneous (tc) gasimetry are widely used noninvasive technologies that allow sensible, continuous and real-time quantification of circulation related variables ${ }^{[3-6]}$. These technologies, often coupled to "provocation" tests, are designed to change the resting perfusion conditions and stimulate vascular reactivity, therefore providing dynamic information regarding the mechanisms involved in that response ${ }^{[5,6]}$. These tests modify perfusion conditions, either systemically, as with postural changes ${ }^{[5]}$, limb occlusion, ${ }^{[5]}$ and oxygen breathing, ${ }^{[6]}$ or locally, as with thermal stimulation ${ }^{[7]}$ and topical drug application ${ }^{[8]}$. Methyl nicotinate (MN) is a potent vasodilator that has been previously used to assess skin microvascular reactivity ${ }^{[8-12]}$. Topical application of $\mathrm{MN}$ induces a rapid local vasodilatation, clinically expressed as a cutaneous erythema, easily recorded with LDF ${ }^{[8,9]}$. The effects of age ${ }^{[9]}$, gender ${ }^{[12]}$ and skin location ${ }^{[10,13]}$ on the response to $\mathrm{MN}$ have already been studied and described. However, the effect of local perfusion conditions in this response needs clarification. The purpose of this study was to investigate the peripheral microvascular reactivity to $\mathrm{MN}$ under distinct reduced perfusion conditions.

\section{Material and Methods}

15 healthy volunteers participated in this study, 8 females and 7 males, $(23.1 \pm 3.0)$ years old average age, giving their informed consent. The study was developed in accordance with the Declaration of Helsinki and its subsequent amendments ${ }^{[14]}$ and evaluated by the institutional ethical commission.

All subjects were non-smokers and previously asked to restrain from consuming caffeine or alcohol-containing beverages, and the application of topical (cosmetic) products to the feet 24 hours before the experiments. Acclimatization to the room conditions was achieved in the sitting position having both feet exposed, for 30 minutes. Individuals remained in the room, under constant temperature at $(21 \pm 2){ }^{\circ} \mathrm{C}$ and $(40-60) \%$ relative humidity.

Variables, obtained in one randomly chosen foot, involved microcirculatory blood flow, recorded in the superior aspect of the foot by Laser Doppler Flowmetry (PF5010, Perimed, Sweden) expressed in arbitrary units (AUs), attaching the probe to the skin with a dou-

\section{Introdução}

A pele fornece uma rede vascular de fácil acesso para o estudo dos mecanismos fisiológicos e disfuncionais da regulação do fluxo sanguíneo ${ }^{[1,2]}$. A Fluxometria por Laser Doppler (FLD) e gasimetria transcutânea (tc) são tecnologias não-invasivas amplamente utilizadas que permitem a quantificação sensível, contínua e em tempo real de variáveis relacionadas com a circulação ${ }^{[3-6]}$. Estas tecnologias são muitas vezes associadas a testes de "provocação", destinados a alterar as condições de perfusão em repouso e estimular a reatividade vascular, fornecendo informação dinâmica a respeito dos mecanismos envolvidos nessa resposta ${ }^{[5,6]}$. Estes testes alteram as condições de perfusão, quer sistemicamente, como em alterações posturais ${ }^{[5]}$, na oclusão de um membro ${ }^{[5]}$ e na inalação de oxigénio ${ }^{[6]}$ quer localmente, como na estimulação térmica ${ }^{[7]}$, e na aplicação de fármacos ${ }^{[8]}$. O nicotinato de metilo (NM) é um potente vasodilatador que tem sido utilizado para avaliar a reactividade microvascular cutânea ${ }^{[8-12]}$. A aplicação tópica de NM induz uma rápida vasodilatação local, expressa através de um eritema cutâneo, facilmente registado com FLD ${ }^{[8,9]}$. Os efeitos da idade ${ }^{[9]}$, do género ${ }^{[12]}$ e da zona da pele ${ }^{[10,13]}$ na resposta ao NM foram já estudados. No entanto, o efeito das condições de perfusão locais nesta resposta necessita de esclarecimento. O objetivo deste estudo foi investigar a reatividade microvascular periférica ao NM em duas condições distintas de perfusão reduzida.

\section{Material e Métodos}

15 voluntários saudáveis participaram neste estudo, 8 mulheres e 7 homens, com média de idade $(23,1 \pm 3,0)$ anos, tendo dado o seu consentimento informado. $\mathrm{O}$ estudo foi desenvolvido de acordo com a Declaração de Helsínquia e suas emendas posteriores ${ }^{[14]}$ e avaliado pela comissão de ética da instituição.

Todos os indivíduos eram não-fumadores e previamente convidados a absterem-se de consumir bebidas contendo cafeína ou álcool, e aplicar produtos tópicos (cosméticos) nos pés 24 horas antes das experiências. A aclimatização às condições da sala foi alcançada na posição sentada com ambos os pés expostos, durante 30 minutos. Os indivíduos permaneceram na sala, a temperatura constante de $(21 \pm 2){ }^{\circ} \mathrm{C}$ e humidade relativa (40-60) \%.

As variáveis estudadas, obtidas num pé escolhido aleatoriamente, envolveram o fluxo sanguíneo microcirculatório na face superior do pé, expresso em unidades arbitrárias (UA) por Fluxometria por Laser Doppler (PF5010, Perimed, Suécia), fixando a sonda à pele com 
ble-sided tape strip (PF 105-3, Perimed, Sweden); and oxygen transcutaneous partial pressure $\left(t c p_{\mathrm{O}_{2}}\right)$ recorded in the superior aspect of the foot on the projection of the root of the second toe, by transcutaneous gasimetry (PF5040 tcp $\mathrm{O}_{2} / t c p_{\mathrm{CO}_{2}}$ System, Perimed, Sweden), expressed in $\mathrm{mmHg}$.

Two protocols, as illustrated in figure 1, involving the topical application of a $0.1 \mathrm{M}$ aqueous solution of $\mathrm{MN}$ (Sigma-Aldrich, Dorset, United Kingdom) on the superior aspect of the foot using a saturated filter paper (4 $\mathrm{cm}^{2}$ square) were performed in sequence, as follows:

Protocol 1: in the seated volunteer, MN was applied for exactly 60 seconds; immediately after removal of the filter paper, the LDF probe was attached to the skin and blood flow was recorded for 15 minutes; after this period, vasoconstriction-induced hyperoxia is induced by breathing a saturated normobaric oxygen atmosphere (Medicinal Oxygen, Air Liquid, Portugal) for 13 minutes. This corresponds to the time sufficient to provide an adequate hyperoxic state for the drug application duration $(\sim 16 \mathrm{~min})$ as published previously ${ }^{[6]}$. MN was also applied to a second skin zone, close to the first, for 60 seconds and blood flow was recorded for another 15 minutes on filter paper removal.

Protocol 2: The volunteer assumed a supine position and MN was applied for exactly 60 seconds; immediately after removal of the soaked filter paper, the LDF probe was attached to the skin and blood flow recorded for 15 minutes; after this period, perfusion reduction was induced by a passive leg elevation of $45^{\circ}$, maintained for 18 minutes, the time determined to be necessary to maintain this haemodynamic state during the $\mathrm{MN}$ application. MN was also applied to a second skin zone, close to the first, for 60 seconds and blood flow was recorded for 15 another minutes. uma fita adesiva dupla (PF 105-3, Perimed, Suécia); e $t c p_{\mathrm{O}_{2}}$ na face superior do pé, na projecção da raíz do segundo dedo, por gasimetria transcutânea (Sistema PF5040 tcp $\mathrm{O}_{2} /$ tcp $\mathrm{CO}_{2}$, Perimed, Suécia).

Foram realizadas experiências segundo dois protocolos, como ilustrado na figura 1, envolvendo a aplicação tópica de uma solução aquosa 0,1 M de NM (SigmaAldrich, Dorset, Reino Unido) sobre a face superior do pé, utilizando um papel de filtro saturado (quadrado de $4 \mathrm{~cm}^{2}$ ) em sequência, como se segue:

Protocolo 1: com o voluntário sentado, é aplicado NM durante 60 segundos; imediatamente após a remoção do papel de filtro, a sonda de FLD é fixa à pele e o fluxo sanguíneo é registado durante 15 minutos; após este período, é induzida a vasoconstrição por hiperóxia pela respiração de uma atmosfera normobárica saturada de oxigénio (Oxigénio Medicinal, Air Liquid, Portugal) por 13 minutos, um tempo suficientemente longo para criar hiperóxia durante toda a aplicação ( $\sim 16 \mathrm{~min})$, de acordo comum estudo recente ${ }^{[6]}$. O NM é aplicado a uma segunda zona da pele, próxima da primeira durante 60 segundos, sendo o fluxo sanguíneo registado por mais 15 minutos.

Protocolo 2: o voluntário encontra-se em decúbito dorsal e o NM é aplicado durante 60 segundos; imediatamente após a remoção do papel de filtro, a sonda de FLD é fixa à pele e o fluxo sanguíneo é registado durante 15 minutos; após este tempo, é induzida uma redução da perfusão por elevação passiva da perna a $45^{\circ}$ durante 18 minutos, um tempo suficientemente longo para manter este estado hemodinâmico durante toda a aplicação de NM. O NM é aplicado a uma segunda zona da pele, próxima da primeira durante 60 segundos e o fluxo sanguíneo é registada por mais 15 minutos.
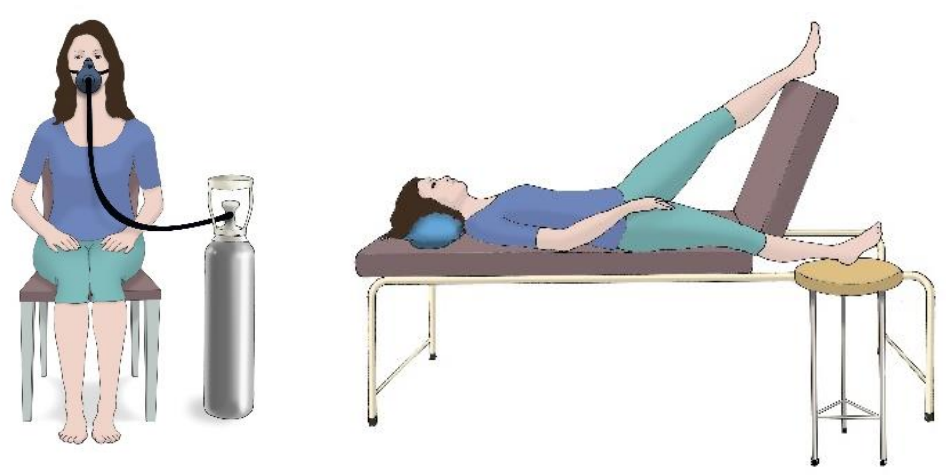

Figure 1 / Figura 1. Illustrative schemes of the tests performed by the volunteers during $\mathrm{MN}$ application in protocols 1 (left) and 2 (right).

Esquemas ilustrativos dos testes realizados pelos voluntários durante a aplicação de NM nos protocolos 1 (esquerda) e 2 (direita). 
On the MN-induced blood flow response record, three phases were visually identified - baseline (onset), hyperemia and plateau phases (Figure 2).
No registo da resposta do fluxo sanguíneo induzido por $\mathrm{NM}$, foram identificadas visualmente três fases - linha de base (início), fases de hiperémia e plateau.
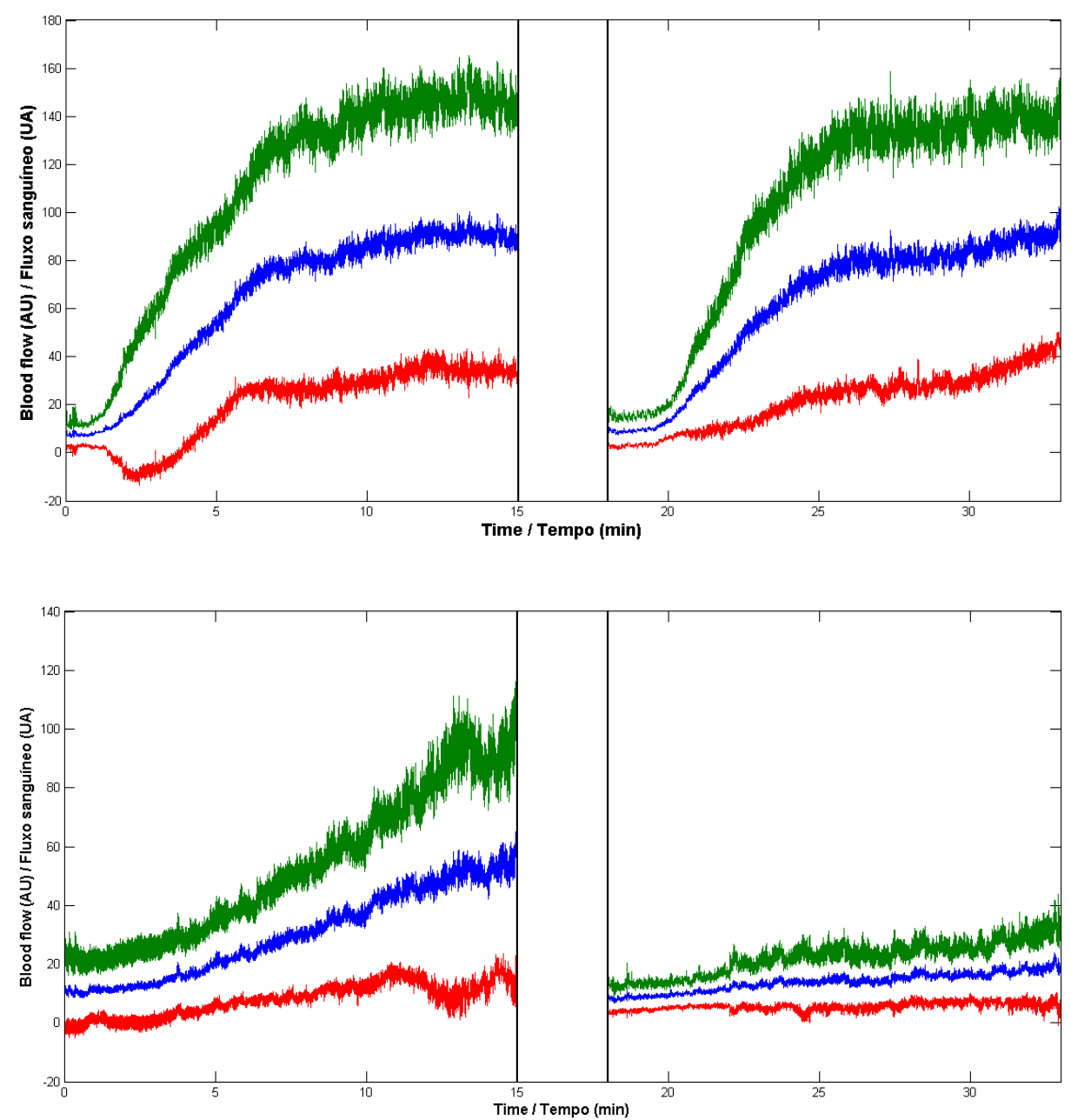

Figure 2 / Figura 2. Recording of blood flow over time for protocols 1 (top) and 2 (bottom). The first and second vertical lines represent the end of the first and the beginning of the second $\mathrm{MN}$ applications, respectively (blue: mean; green: mean + standard deviation; red: mean - standard deviation).

Registo do fluxo sanguíneo ao longo do tempo para os protocolos 1 (em cima) e 2 (em baixo). As linhas verticais representam o fim da primeira e o início da segunda aplicação de $\mathrm{MN}$, respetivamente (azul: média; verde: média + desvio-padrão; vermelho: média - desvio-padrão). 
Mean blood flows and AUC (Area Under the Curve) were calculated from the raw blood flow data for each phase and for the full response. Additional parameters included $t_{\text {onset }}$ - time needed for the beginning of the vascular response; maximum flow - magnitude of the maximum blood flow; $t_{\max }$ - time needed for reaching a maximum blood flow and the mean $t c p_{\mathrm{O}_{2}}$ during the response (Table 1).

Comparison of the parameters respecting all phases in each protocol was performed with the Wilcoxon matched-pairs signed-rank test with the adoption of a $95 \%$ confidence level (IBM SPSS Statistics for Windows, Versão 20.0. Armonk, NY: IBM Corp).
Foram calculados a média do fluxo de sangue e ASC (Área Sob a Curva) a partir dos dados em bruto do fluxo sanguíneo, para cada fase e para a resposta completa. Parâmetros adicionais incluíram $t_{\text {inicio }}$ - tempo necessário para o início da resposta vascular; fluxo máximo - amplitude do fluxo sanguíneo máximo; $t_{\text {máx }}$ - tempo necessário para atingir o fluxo sanguíneo máximo; e média da $t c p_{\mathrm{O}_{2}}$ durante a resposta (Tabela 1).

A comparação dos parâmetros respeitantes a todas as fases em cada protocolo foi realizada com o teste de Wilcoxon para amostras emparelhadas com a adoção de um nível de confiança de $95 \%$ (IBM SPSS Statistics para Windows, Versão 20.0 Armonk, NY:. IBM Corp).

Table 1 / Tabela 1. Mean \pm standard deviation of the determined variables. Statistical comparison for each variable between phases of each protocol (NA - non applicable; * statistical significant).

Média \pm desvio-padrão das variáveis determinadas. Comparação estatística para cada variável entre as fases de cada protocolo (NA - não aplicável; * - estatisticamente significativo).

\begin{tabular}{|c|c|c|c|c|c|c|}
\hline \multirow[b]{2}{*}{ Parameter } & \multicolumn{3}{|c|}{ Protocol 1} & \multicolumn{3}{|c|}{ Protocol 2} \\
\hline & $\begin{array}{c}\text { Room } \\
\text { atmosphere }\end{array}$ & $\mathrm{O}_{2}$ breathing & $p$-value & Supine & Elevation & $p$-value \\
\hline $\begin{array}{l}t_{\text {onset }} / \mathrm{s} \\
t_{\text {início }} \& \mathrm{~s}\end{array}$ & $194.8 \pm 125.6$ & $186.8 \pm 140.9$ & 0.594 & NA & NA & NA \\
\hline $\begin{array}{l}\text { Baseline blood flow / AU } \\
\text { Fluxo sanguíneo basal / } \\
\text { UA }\end{array}$ & $8.6 \pm 4.1$ & $9.2 \pm 4.8$ & 0.551 & NA & NA & NA \\
\hline $\begin{array}{l}\text { AUC baseline / (AU s) } \\
\text { ASC basal / (UA s) }\end{array}$ & $1603.9 \pm 1301.2$ & $1594.2 \pm 1126.7$ & 0.826 & NA & NA & NA \\
\hline $\begin{array}{l}\text { Hyperemic phase blood } \\
\text { flow / AU } \\
\text { Fluxo sanguíneo fase } \\
\text { hiperémica / UA }\end{array}$ & $53.4 \pm 25.8$ & $57.5 \pm 37.1$ & 0.638 & NA & NA & NA \\
\hline $\begin{array}{l}\text { Maximum blood flow / AU } \\
\text { Fluxo sanguíneo máximo / } \\
\text { UA }\end{array}$ & $108.6 \pm 52.5$ & $122.9 \pm 72.8$ & 0.331 & NA & NA & NA \\
\hline $\begin{array}{l}\boldsymbol{t}_{\max } / \mathrm{s} \\
\boldsymbol{t}_{\mathrm{max}} / \mathrm{s}\end{array}$ & $454.8 \pm 150.7$ & $511.0 \pm 160.1$ & 0.433 & NA & NA & NA \\
\hline $\begin{array}{l}\text { AUC hyperemic phase / } \\
\text { (AU s) } \\
\text { ASC fase hiperémica / (UA } \\
\text { s) }\end{array}$ & $14124.4 \pm 8020.2$ & $\begin{array}{c}18574.5 \pm \\
12641.5\end{array}$ & 0.198 & NA & NA & NA \\
\hline $\begin{array}{l}\text { Plateau phase blood flow / } \\
\text { (AU s) } \\
\text { Fluxo sanguíneo plateau / } \\
\text { (UA s) }\end{array}$ & $89.8 \pm 48.7$ & $97.4 \pm 56.1$ & 0.331 & NA & NA & NA \\
\hline $\begin{array}{l}\text { AUC plateau phase / (AU s) } \\
\text { ASC fase plateau / (UA s) }\end{array}$ & $42752.7 \pm 28491.9$ & 43797.4 & 0.363 & NA & NA & NA \\
\hline $\begin{array}{l}\text { Blood flow full response / } \\
\text { AU } \\
\text { Fluxo sanguíneo resposta } \\
\text { completa / UA }\end{array}$ & $62.2 \pm 38.1$ & $63.0 \pm 36.7$ & 0.910 & $37.5 \pm 23.1$ & $18.1 \pm 10.5$ & $0.002^{*}$ \\
\hline $\begin{array}{l}\text { AUC full response / (AU s) } \\
\text { ASC resposta completa / } \\
\text { (UA s) }\end{array}$ & $59651.3 \pm 32779.0$ & $\begin{array}{c}66321.3 \pm \\
39838.0\end{array}$ & 0.570 & $\begin{array}{c}32393.5 \pm \\
20455.3\end{array}$ & $\begin{array}{c}16428.0 \pm \\
10090.9\end{array}$ & $0.002^{*}$ \\
\hline $\begin{array}{l}\text { Mean tcpO } / \mathrm{mmHg} \\
\text { tcpO } \\
\mathrm{cpO}_{2} \text { médio } / \mathrm{mmHg}\end{array}$ & $81.8 \pm 12.5$ & $224.69 \pm 3.2$ & $0.001^{*}$ & $77.0 \pm 10.5$ & $48.6 \pm 19.5$ & $0.002^{*}$ \\
\hline
\end{tabular}




\section{Results and Discussion}

Methyl nicotinate penetrates the epidermis and acts upon the dermal capillaries, causing vasodilation through the production of prostaglandin $\mathrm{D}_{2}{ }^{[10]}$. Because only finite doses of $\mathrm{MN}$ are applied, the vascular response evolves a maximum and then decays, as a consequence of its uptake into the capillaries and systemic dilution ${ }^{[9]}$.

This typical hyperemic record was obtained for the seated position of protocol 1 but not for the supine position of protocol 2 (Figure 2), which in this case impaired calculation all of the curve-dependent parameters.

The hyperoxia evoked by the oxygen breathing promoted a reflex vasoconstriction in several vascular beds, including the skin ${ }^{[6]}$. Despite of this effect, no statistical differences between parameters were found when the volunteer was breathing room air or oxygen, indicating that the MN-induced vasodilation mechanisms overpassed the hyperoxia-mediated blood flow reduction mechanisms. Recent studies reported different effects of hyperoxia on skin vasodilation mediated by different drugs ${ }^{[15,16]}$. However, none of these studies involved the application of $\mathrm{MN}$.

The passive leg elevation caused a perfusion reduction in the foot which seems to be secondary to the gravitational transfer of blood towards the superior extremity of the body ${ }^{[5]}$. This likely justifies the significant reduction of the magnitude of $\mathrm{MN}$-induced vasodilation when compared to the stimulation in the supine position without elevation.

A relevant inter-individual variation to the volunteer's response to $\mathrm{MN}$ was noted and expected. Nevertheless, the usefulness of this model to test cutaneous microcirculatory reactivity, including the use of $\mathrm{MN}$, is demonstrated no matter the need to improve eventual variability sources identified here.

\section{Conclusions}

In the present experimental conditions, the hyperoxiainduced vasoconstriction does not reduce the magnitude of the methyl nicotinate vasodilation, while the postural perfusion reduction modifies this vasodilation profile and reduces the overall response. Further studies are needed to investigate further into the mechanisms involved.

\section{Resultados e discussão}

O nicotinato de metilo penetra na epiderme e atua sobre os capilares da derme, causando vasodilatação através da produção de prostaglandina $\mathrm{D}_{2}{ }^{[10]}$. Dado que apenas doses finitas de MN são aplicadas, a resposta vascular passa por um máximo e depois decai, como consequência da sua captação pelos capilares e diluição sistémica [9].

Este registo típico hiperémico foi obtido para a posição sentada do protocolo 1 , mas não para a posição supina do protocolo 2 (Figura 2), que, neste caso, impediu o cálculo de todos os parâmetros dependentes da curva.

A hiperóxia provocada pela respiração de oxigénio promoveu uma vasoconstrição reflexa em várias redes vasculares, incluindo a pele ${ }^{[6]}$. Apesar deste efeito, não foram encontradas diferenças estatísticas entre os parâmetros quando o voluntário respirou ar ou oxigénio, o que significa que os mecanismos de vasodilatação induzida por NM ultrapassam os mecanismos de redução do fluxo sanguíneo mediada pela hiperóxia. Estudos recentes relataram diferentes efeitos da hiperóxia sobre a vasodilatação mediada por diferente fármacos ${ }^{[15,16]}$. No entanto, nenhum destes estudos envolveu a aplicação de NM.

A elevação passiva da perna causou uma redução de perfusão do pé, que parece ser secundário à transferência gravitacional de sangue para a extremidade superior do corpo ${ }^{[5]}$. Isto provavelmente justifica a redução significativa da amplitude da vasodilatação induzida por NM quando comparada com a estimulação na posição supina sem elevação.

Foi notada uma já esperada variação interindividual relevante para a resposta do voluntário ao NM. Ainda assim, a utilidade deste modelo para testar a reatividade microcirculatória cutânea, incluindo o uso de NM, é demonstrado, não obstante a necessidade de reduzir as eventuais fontes de variabilidade aqui identificadas.

\section{Conclusões}

Nas presentes condições experimentais, a vasoconstrição induzida por hiperóxia não reduz a amplitude da vasodilatação do nicotinato de metilo, enquanto que a redução postural da perfusão modifica este perfil de vasodilatação e reduz a resposta global. São necessários mais estudos para investigar mais detalhadamente para os mecanismos envolvidos. 


\section{Acknowledgements}

The authors would like to express their thanks to Sara Aguiar Silva for the collaboration and assistance and to all volunteers for their participation.

\section{Conflict of Interests}

The authors declare that there are no financial and/or personal relationships that could be viewed as presenting a potential conflict of interests.

\section{Agradecimentos}

Os autores gostariam de expressar os seus agradecimentos a Sara Aguiar Silva pela colaboração e assistência e a todos os voluntários pela sua participação.

\section{Conflito de Interesses}

Os autores declaram não existir qualquer relação pessoal ou financeira que possa ser entendida como representando um potencial conflito de interesses. 


\section{References / Referências}

1. Abularrage CJ, Sidawy AN, Aidinian G, Singh N, Weiswasser JM, Arora S. Evaluation of the microcirculation in vascular disease. J Vasc Surg 2005; 42:574-81.

2. Holowatz LA, Thompson-Torgerson CS, Kenney WL. The human cutaneous circulation as a model of generalized microvascular function. J Appl Physiol 2008; 105:370-2.

3. Rajan V, Varghese B, van Leeuwen TG, Steenbergen W. Review of methodological developments in laser Doppler flowmetry. Lasers Med Sci 2009; 24:269-83.

4. Hauser CJ, Shoemaker WC. Use of a transcutaneous $\mathrm{PO} 2$ regional perfusion index to quantify tissue perfusion in peripheral vascular disease. Ann Surg 1983; 197:337-43.

5. Silva H, Ferreira H, Tavares L, Bujan J, Rodrigues LM. Exploring in vivo models to characterize peripheral microcirculation - a pilot study. Biomed Biopharm Res 2013; (10)1:65-72.

6. Silva H, Ferreira HA, Bujan J, Rodrigues LM. Exploring the oxygen challenge test as a microcirculation evaluation model. Biomed Biopharm Res 2013; (10)2:209-215.
7. Minson CT, Holowatz L A, Wong BJ, Kenney WL, Wilkins BW. Decreased nitric oxide- and axon reflex-mediated cutaneous vasodilation with age during local heating. $\mathrm{J}$ Appl Physiol 2002; 93:1644-9.

8. Koivukangas V, Oikarinen A, Salmela PI, Lahti A. Microcirculatory response of skin to benzoic acid and methyl nicotinate in patients with diabetes. Diabet Med 2000;17(2):130-3.

9. Roskos KV, Bircher AJ, Maibach HI, Guy RH. Pharmacodynamic measurements of methyl nicotinate percutaneous absorption: the effect of aging on microcirculation. $\mathrm{Br} \mathrm{J}$ Dermatol 1990;122(2):165-71.

10. Caselli A, Hanane T, Jane B, Carter S, Khaodhiar L, Veves A. Topical methyl nicotinate-induced skin vasodilation in diabetic neuropathy. J Diabetes Complications 2003;17(4):205-10.

11. Rosado C, Rodrigues LM. Assessment of dry skin using dynamic methods. Journal of Applied Cosmetology 2006;24:149-57.
12. Gean CJ, Tur E, Maibach HI, Guy RH. Cutaneous responses to topical methyl nicotinate in black, oriental, and caucasian subjects. Arch Dermatol Res 1989;281(2):95-8.

13. Elsner P, Maibach HI. Cutaneous responses to topical methyl nicotinate in human forearm and vulvar skin. J Dermatol Sci 1991;2(5):341-5.

14. World Medical Association. World Medical Association Declaration of Helsinki: ethical principles for medical research involving human subjects. JAMA 2013; 310:2191-4.

15. Yamazaki F. Hyperoxia attenuates endothelial-mediated vasodilation in the human skin. J Physiol Sci 2007;57(1):81-4.

16. Rousseau A, Tesselaar E, Henricson J, Sjöberg F. Prostaglandins and radical oxygen species are involved in microvascular effects of hyperoxia. J Vasc Res 2010;47(5):441-50. 